\title{
Diclofenac-Induced Apoptosis in the Neuroblastoma Cell Line SH-SY5Y: Possible Involvement of the Mitochondrial Superoxide Dismutase
}

\author{
Francesca Cecere, ${ }^{1}$ Annarita Iuliano, ${ }^{1}$ Francesco Albano, ${ }^{1}$ Claudia Zappelli,, \\ Immacolata Castellano, ${ }^{1}$ Pasquale Grimaldi, ${ }^{1}$ Mariorosario Masullo, ${ }^{1,2}$ \\ Emmanuele De Vendittis, ${ }^{1}$ and Maria Rosaria Ruocco ${ }^{1}$ \\ ${ }^{1}$ Dipartimento di Biochimica e Biotecnologie Mediche, Università degli Studi di Napoli Federico II, Via S. Pansini 5, \\ 80131 Napoli, Italy \\ ${ }^{2}$ Dipartimento di Studi delle Istituzioni e dei Sistemi Territoriali, Università degli Studi di Napoli "Parthenope”, Via Medina 40, \\ 80133 Napoli, Italy
}

Correspondence should be addressed to Maria Rosaria Ruocco, ruocco@dbbm.unina.it

Received 8 January 2010; Revised 18 March 2010; Accepted 10 April 2010

Academic Editor: George Perry

Copyright (C) 2010 Francesca Cecere et al. This is an open access article distributed under the Creative Commons Attribution License, which permits unrestricted use, distribution, and reproduction in any medium, provided the original work is properly cited.

\begin{abstract}
Diclofenac, a nonsteroidal anti-inflammatory drug, induces apoptosis on the neuroblastoma cell line SH-SY5Y through a mitochondrial dysfunction, affecting some antioxidant mechanisms. Indeed, the time- and dose-dependent increase of apoptosis is associated to an early enhancement of the reactive oxygen species (ROS). Mitochondrial superoxide dismutase (SOD2) plays a crucial role in the defence against ROS, thus protecting against several apoptotic stimuli. Diclofenac decreased the protein levels and the enzymatic activity of SOD2, without any significant impairment of the corresponding mRNA levels in the SH-SY5Y extracts. When cells were incubated with an archaeal exogenous thioredoxin, an attenuation of the diclofenac-induced apoptosis was observed, together with an increase of SOD2 protein levels. Furthermore, diclofenac impaired the mitochondrial membrane potential, leading to a release of cytochrome $c$. These data suggest that mitochondria are involved in the diclofenac-induced apoptosis of SH-SY5Y cells and point to a possible role of SOD2 in this process.
\end{abstract}

\section{Introduction}

Reactive oxygen species (ROS), normally produced during the aerobic metabolism, function as second messengers involved in many cellular functions. On the other hand, when ROS level increases because of oxidant treatments and/or defective antioxidant systems, these highly reactive compounds and radicals become dangerous toxic agents. In fact, ROS may cause severe damages to several cellular macromolecules, including proteins, lipids, and DNA, thus contributing to the development of many pathological conditions. Indeed several evidences have been reported, indicating that the redox homeostasis is a finely regulated mechanism involved in normal cellular functions and prevention of several stress-associated pathologies [1].
Many drugs have toxic side effects, because they provoke an imbalance of the intracellular ROS level. In the past, cellular death due to a chemical injury was frequently linked to a necrotic process; now, it is clear that the main effect provoked by several drugs is the programmed cell death [2]. Diclofenac, a nonsteroidal anti-inflammatory drug (NSAID) widely used in clinical therapeutics, has cytotoxic effects and induces apoptosis in many cultured cell lines $[3,4]$. This behaviour is common even to other NSAIDs and some anticancer agents. Indeed, many experimental, epidemiologic and clinical studies suggest that NSAIDs, and in particular the highly selective cyclooxigenase-2 inhibitors, could act as anticancer agents $[5,6]$. It has been reported that a combination of a specific NSAID and certain anticancer drugs has potential clinical applications. For instance, 
diclofenac potentiates the chemotherapeutic effects of some drugs in neuroblastoma cell lines [7]. However, little is known about the effect of this NSAID on nervous cell lines [8], because most of the studies on this compound regard hepatic, gastric, or kidney cells $[3,4,9]$. In particular, ROS are involved in the diclofenac-induced apoptosis of cultured gastric cells as well as in nephrotoxicity in vivo $[9,10]$; furthermore, an oxidative injury causes the mitochondrial permeability transition in diclofenac-treated hepatocytes [11]. However, the molecular mechanisms underlying the induction of apoptosis by diclofenac have not been clarified in neuronal cells.

In this paper, we have investigated the involvement of mitochondrial dysfunction in the mechanism of diclofenacinduced apoptosis in the neuroblastoma cell line SH-SY5Y. In particular, we have analyzed the role of the manganese superoxide dismutase (SOD2) in this process. SOD2 is a key enzyme of the mitochondrial matrix involved in the protection against oxidative stress, which converts the toxic superoxide anions to hydrogen peroxide and molecular oxygen. Numerous reports have demonstrated that SOD2 has an essential role in the protection against many apoptotic stimuli [12-14]. In fact, in mice a partial deficiency of the SOD2 gene $(\operatorname{sod} 2(+/-))$ increases the sensitivity to apoptosis [15], whereas its overexpression has an antiapoptotic effect. In particular, SOD2 is involved in the inhibition of the mitochondrial permeability transition after cell treatment with tumor necrosis factor- $\alpha$ or ionizing radiations [1618], and blocks the Fas-mediated apoptosis [19, 20]. Our data show that the treatment of the neuroblastoma cell line SH-SY5Y with diclofenac induces a decrease in SOD2 protein level and an increase of the ROS concentration. This impaired redox balance predisposes the cell to apoptosis through a mechanism involving the mitochondrial pathway.

\section{Materials and Methods}

2.1. Chemicals. RPMI 1640 medium, fetal bovine serum (FBS), L-glutamine, penicillin G, streptomycin and trypsin were purchased from Cambrex. Diclofenac was obtained from Calbiochem. Rhodamine 123 (R123), dichlorofluorescein diacetate (DCFH-DA), and propidium iodide were purchased from Sigma. A protease inhibitor cocktail was obtained from Roche Diagnostics. Polyclonal antibody against human SOD2 was purchased from Upstate; polyclonal antibody against GAPDH was obtained from Cell signaling; polyclonal antibody against $\beta$-tubulin, goat polyclonal antibody against Cox-4, monoclonal antibody against cytochrome $c$, and each secondary antibody conjugated to horseradish peroxidase were obtained from Santa Cruz Biotechnology. Recombinant thioredoxin A2 from the hyperthermophilic archaeon Sulfolobus solfataricus (SsTrx) was obtained as previously reported [21]. All other chemicals were of analytical grade and were purchased from Sigma.

2.2. Cell Culture. The human neuroblastoma cell line SHSY5Y was obtained from American Type Culture Collection. SH-SY5Y cells were grown in RPMI 1640 medium supplemented with $10 \% \mathrm{FBS}, 2 \mathrm{mM}$ L-glutamine, $100 \mathrm{IU} / \mathrm{ml}$ penicillin $\mathrm{G}$, and $100 \mu \mathrm{g} / \mathrm{ml}$ streptomycin, in humidified incubator at $37^{\circ} \mathrm{C}$ under $5 \% \mathrm{CO}_{2}$ atmosphere. They were split and seeded in plates $\left(75 \mathrm{~cm}^{2}\right)$ every three days and used for assays during exponential phase of growth.

2.3. Cytotoxicity Assay. An increasing concentration of diclofenac was added to cultures, and cells were incubated for different times. Cytotoxicity was quantitatively assessed by measurements of lactate dehydrogenase (LDH) activity released in the extracellular fluid from damaged or destroyed cells [22]. Briefly, different aliquots of cell incubation media were added to a $1-\mathrm{ml}$ reaction mixture containing $0.1 \mathrm{M}$ Tris- $\mathrm{HCl}, \mathrm{pH} 7.5,125 \mu \mathrm{M} \mathrm{NADH}$, and incubated for 15 minutes at $30^{\circ} \mathrm{C}$. The reaction started with the addition of $600 \mu \mathrm{M}$ sodium pyruvate and was followed by the decrease in absorbance at $340 \mathrm{~nm}$. The results were normalized to $100 \%$ death caused by cell sonication.

2.4. Evaluation of Apoptosis. To determine the number of apoptotic nuclei in diclofenac-treated cells, $3 \times 10^{4}$ cells/well were seeded into 96-well plates; at the end of each treatment, cell suspensions were centrifuged and pellets were resuspended in a hypotonic lysis solution containing $50 \mu \mathrm{g} / \mathrm{ml}$ propidium iodide. After incubation at $4{ }^{\circ} \mathrm{C}$ for 30 minutes, cells were analysed by flow cytometry to evaluate the presence of nuclei with a DNA content lower than the diploid [23].

2.5. Detection of Intracellular ROS Content. The intracellular ROS level was detected using the oxidation-sensitive fluorescence probe DCFH-DA [11]. Briefly, cells were seeded into 6 -well plate $\left(3 \times 10^{5}\right.$ cells/well $)$ and treated with $150 \mu \mathrm{M}$ diclofenac for different times. DCFH-DA was added in the dark at $10 \mu \mathrm{M}$ final concentration 30 minutes before the end of each incubation; then cells were collected, washed in $10 \mathrm{mM}$ sodium phosphate, $\mathrm{pH} 7.2$ buffer containing $150 \mathrm{mM}$ $\mathrm{NaCl}$ (PBS), and finally resuspended in $500 \mu \mathrm{L}$ of PBS for the fluorimetric analysis. The measurement of the ROS levels was realised with a Cary Eclipse fluorescence spectrophotometer (Varian). Excitation and emission wavelengths were $485 \mathrm{~nm}$ and $530 \mathrm{~nm}$, respectively; both excitation and emission slits were set at $10 \mathrm{~nm}$.

2.6. Reverse Transcriptase Polymerase Chain Reaction. For the analysis of SOD2 mRNA expression, total RNA was extracted from $1 \times 10^{6}$ cells using a Trizol Reagent (Invitrogen) as described by the manufacturer. The yield and integrity of each RNA sample were checked spectrophotometrically at $260 \mathrm{~nm}$ and by agarose gel electrophoresis, respectively. Equal amounts of RNA $(2-4 \mu \mathrm{g})$ were subjected to a reverse transcriptase polymerase chain reaction (RT-PCR), using a specific kit (Invitrogen) and random primers; three dilutions of cDNA were amplified by PCR using Taq DNA polymerase (Invitrogen). For DNA amplification of both SOD2 and glyceraldehyde-3-phosphate dehydrogenase $(\mathrm{GAPDH})$, the PCR program was 5 minutes initial denaturation at $95^{\circ} \mathrm{C}, 20-23$ cycles of amplification $\left(95^{\circ} \mathrm{C}, 1\right.$ minute; $50^{\circ} \mathrm{C}, 1$ minute; $72^{\circ} \mathrm{C}, 1$ minute), final extension 
step at $72^{\circ} \mathrm{C}$ for 10 minutes. The following primers were used: $5^{\prime}$ d-TACGTGAACAACCTGAACGT-3' (sense) and $5^{\prime}$ d-CAAGCCATGTATCTTTCAGTTA (antisense) for SOD2; $5^{\prime} \mathrm{d}$-CACCATCTTCCAGGAGCGAG-3' (sense) and $5^{\prime} \mathrm{d}-$ TCACGCCACAGTTTCCCGGA-3' (antisense) for GAPDH. The amplified cDNA products were analysed by agarose gel electrophoresis. SOD2 PCR products were normalized to the respective intensity of the house-keeping gene GAPDH.

2.7. Evaluation of Mitochondrial Membrane Potential. Mitochondrial membrane potential was evaluated by measuring the incorporation of the fluorescent probe R123. Briefly, cells were seeded into 6 -well plate $\left(3 \times 10^{5}\right.$ cells/well $)$, incubated at $37^{\circ} \mathrm{C}$ for 1 hour in the presence of $5 \mu \mathrm{M}$ R123, washed twice with PBS and placed in fresh complete medium containing $150 \mu \mathrm{M}$ diclofenac. After different times of drug treatment, the medium was withdrawn, and collected cells were washed twice with PBS. After detachment with trypsin, cells were harvested in PBS and centrifuged at $4^{\circ} \mathrm{C}$ for 10 minutes. Following aspiration of supernatant, the cellular pellet was resuspended in $500 \mu \mathrm{L}$ of PBS. The fluorescence of cell-associated R123 was measured in the above-mentioned fluorescence spectrophotometer, using excitation and emission wavelengths of $490 \mathrm{~nm}$ and $520 \mathrm{~nm}$, respectively; both excitation and emission slits were set at $10 \mathrm{~nm}$. The fluorescence intensities were normalized versus the cell number.

2.8. Total Cell Lysates and Western Blotting Analysis. SHSY5Y cells were plated at a density of $3 \times 10^{5}$ cells/well in 6-well plates, and $150 \mu \mathrm{M}$ diclofenac was added to the cultures. After the drug treatment, cells were harvested, washed with PBS, and then lysed in ice-cold modified RIPA buffer (50 mM Tris-HCl, pH 7.4, $150 \mathrm{mM} \mathrm{NaCl}, 1 \%$ Nonidet P-40, $0.25 \%$ sodium deoxycolate, $1 \mathrm{mM} \mathrm{Na}_{3} \mathrm{VO}_{4}$, and $1 \mathrm{mM} \mathrm{NaF}$ ), supplemented with protease inhibitors and incubated for 30 minutes on ice. The supernatant obtained after centrifugation at $12,000 \times \mathrm{g}$ for 30 minutes at $4^{\circ} \mathrm{C}$ constituted the total protein extract. Protein concentration was determined by the method of Bradford [24], using BSA as standard. Western blotting analysis was realised on equal amounts of each total protein extract. Briefly, protein samples were dissolved in SDS/reducing loading buffer, run on a $14 \%$ SDS-PAGE, then transferred to Immobilon $\mathrm{P}$ membrane (Millipore). The filter was incubated with the specific primary antibody at $4^{\circ} \mathrm{C}$ overnight and with the horseradish peroxidase-linked secondary antibody at room temperature for 1 hour. Membranes were then analyzed by an enhanced chemiluminescence reaction, using Super Signal West Pico kit (Pierce) according to the manufacturer's instructions; signals were visualized by autoradiography.

2.9. Subcellular Fractionation for Western Blotting Analysis of Cytochrome c. SH-SY5Y cells were plated at a density of $2 \times 10^{6}$ cells/plate $\left(75 \mathrm{~cm}^{2}\right)$. After treatment with $150 \mu \mathrm{M}$ diclofenac, cells were harvested, washed in PBS, then resuspended in buffer $\mathrm{M}(5 \mathrm{mM}$ Hepes, $\mathrm{pH} 7.4,250 \mathrm{mM}$ mannitol, 0.5 mM EGTA, 0.1\% BSA), supplemented with protease inhibitors, and homogenized. The homogenate was centrifuged at $800 \times \mathrm{g}$ for 10 minutes at $4^{\circ} \mathrm{C}$, and the supernatant was then centrifuged at $12,000 \times \mathrm{g}$ for 30 minutes at $4{ }^{\circ} \mathrm{C}$. The resulting pellet (mitochondrial fraction) was resuspended in buffer $M$ and the final supernatant represented the cytosolic fraction. Protein concentration was determined as previously indicated. Aliquots of both fractions (cytosolic and mitochondrial) were used in Western blotting analysis for the cytochrome $c$ localization.

2.10. Measurement of SOD Activity. SH-SY5Y cells were plated at a density of $2 \times 10^{6}$ cells/plate $\left(75 \mathrm{~cm}^{2}\right)$ and, after one-day plating, $150 \mu \mathrm{M}$ diclofenac was added to the cultures. Cells were then collected at different times as previously indicated and then centrifuged at $300 \times \mathrm{g}$ at $4^{\circ} \mathrm{C}$ for 5 minutes, washed once with PBS, and finally resuspended in $50 \mathrm{mM}$ potassium phoshate, $\mathrm{pH} 7.8$, containing $1 \mathrm{mM}$ EDTA. The cellular suspension was sonicated, centrifuged at $20,000 \times \mathrm{g}$ at $4^{\circ} \mathrm{C}$ for 30 minutes, and after protein quantitation, the supernatant was used for an activity gel assay. In particular, aliquots of cell extracts $(50 \mu \mathrm{g})$ were fractionated on a $10 \%$ polyacrylamide gel and SOD activity was evaluated as previously described [25]. This method is based on the inhibitory effect of SOD on the reduction of nitro-blue tetrazolium by the superoxide anions generated by the photochemical reduction of riboflavin; SOD is visualized as a colourless band over a blue background.

2.11. Statistical Analysis. All results are presented as histograms and data are the average $\pm \mathrm{SD}$ of at least three independent measurements. In particular, data were analyzed by one-way ANOVA, and differences were considered significant when the corresponding $P$-values were $<.05$ in the Bonferroni's post-hoc test.

\section{Results}

3.1. Diclofenac-Induced Apoptosis in the Human Neuroblastoma Cell Line SH-SY5Y. To evaluate whether diclofenac had cytotoxic effects on neuronal cells, the human neuroblastoma cell line SH-SY5Y was incubated for 24 hours with increasing concentrations of diclofenac. Propidium iodide incorporation followed by flow cytometric analysis showed a dose-dependent increase of apoptotic nuclei with subdiploid DNA content (Figure 1(a)). The cytosolic enzyme lactate dehydrogenase (LDH) has been already used as a marker of cytotoxic injury [11]. Indeed, a significant increase of LDH activity is typically found in culture media of cells undergoing a disruption of plasma membrane. To this aim, we have assayed the LDH activity in the culture media of SH-SY5Y cells incubated up to 48 hours with increasing concentrations of diclofenac. No significant release of the intracellular LDH was observed up to $150 \mu \mathrm{M}$ diclofenac (not shown), which was taken as the maximal concentration of this compound not causing a significant cytotoxic effect (MNTC). To analyse the time-dependent increase of apoptosis, SH-SY5Y cells were exposed to $150 \mu \mathrm{M}$ diclofenac and analysed at different times. As shown in Figure 1(b), the 


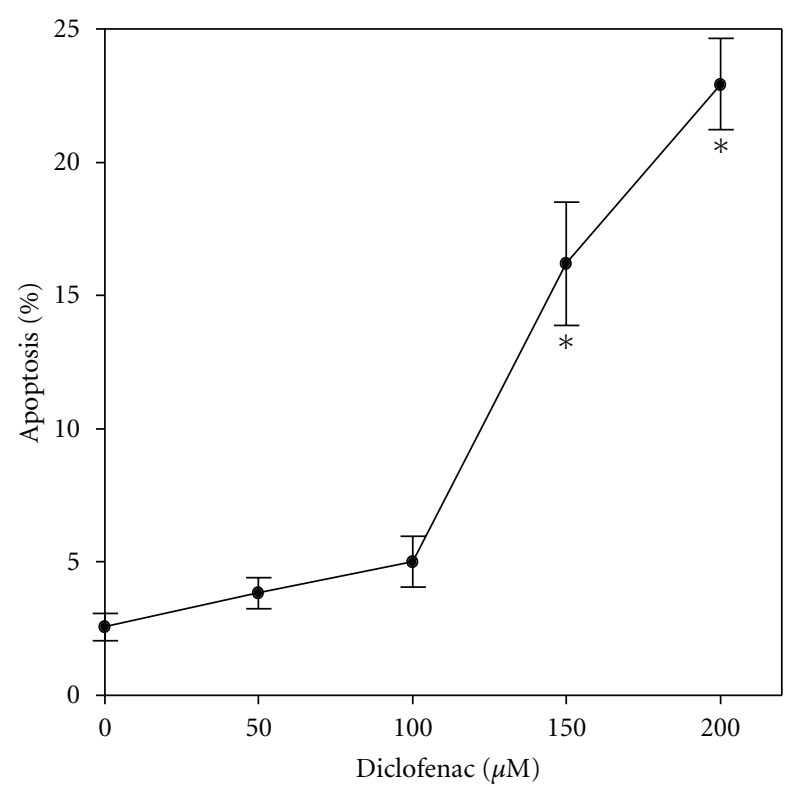

(a)

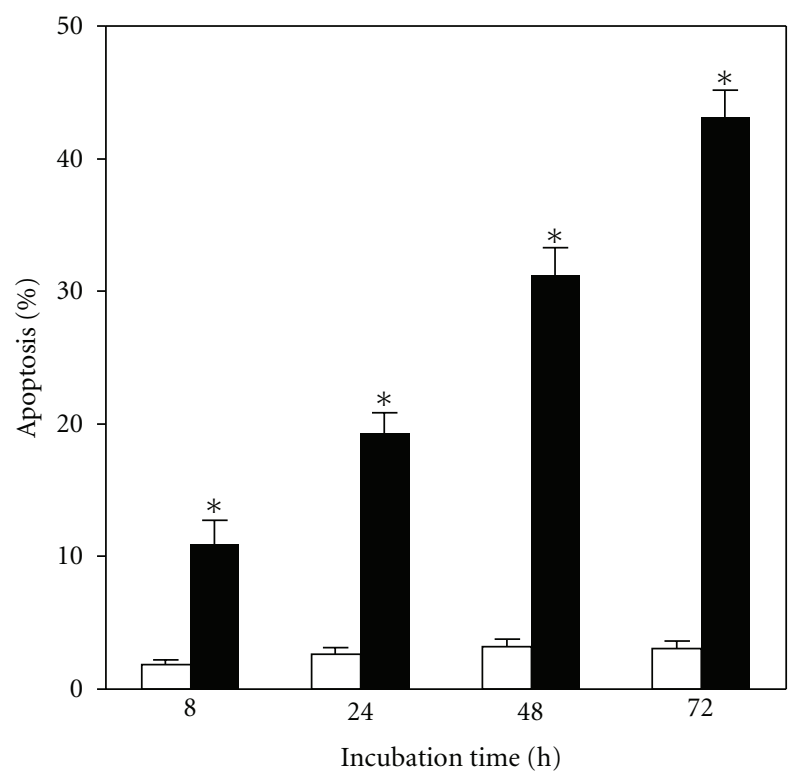

(b)

FIGURE 1: Diclofenac-induced apoptosis in SHSY-5Y cells. (a) SH-SY5Y cells were incubated with the indicated concentrations of diclofenac and apoptosis was evaluated after a 24-hour drug treatment. (b) SH-SY5Y cells were treated with vehicle alone (white bars) or $150 \mu \mathrm{M}$ diclofenac (black bars) and apoptosis was evaluated after the indicated incubation times. The percentage of apoptosis was measured as described in Section $2.4 ;{ }^{*} P<.01$ compared to untreated cells.

apoptotic process was already evident after 8-hour treatment and progressively increased up to 72 hours.

3.2. Effect of Diclofenac on the Intracellular ROS Level. It is known that NSAIDs alter the redox state of different cell types through an enhancement of intracellular ROS levels

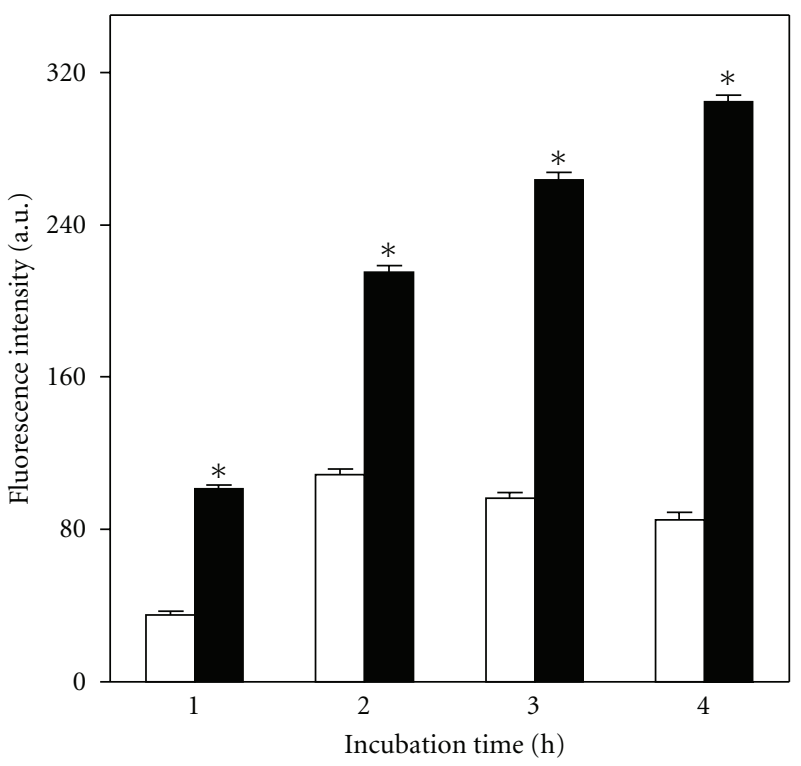

FIGURE 2: Effect of diclofenac on the intracellular ROS level. SHSY5Y cells were incubated with vehicle alone (white bars) or $150 \mu \mathrm{M}$ diclofenac (black bars) for the indicated times. The intracellular ROS level was evaluated through the usage of the fluorescent probe DCFH-DA, as described in Section 2.5. Fluorescence intensity was reported as Arbitrary Units $(\mathrm{AU}) ;{ }^{*} P<.01$ compared to untreated cells.

[9-11]. Therefore, we have decided to investigate whether diclofenac affects the intracellular ROS levels also in SHSY5Y cells, using the fluorescent probe DCFH-DA. Indeed, when these cells were incubated with diclofenac and DCFHDA at different times, an early increase of the ROS level was detected with respect to control cells; furthermore, ROS production progressively continued at least up to 4 hours (Figure 2).

3.3. Effect of Diclofenac on SOD2 Levels. As SOD2 is the primary antioxidant enzyme in mitochondria protecting cells from oxidative injuries, we have evaluated the role exerted by this enzyme in SH-SY5Y cells in the course of diclofenac treatment. To this aim, the dose- and timedependent effects of this drug on SOD2 protein levels of $\mathrm{SH}-\mathrm{SY} 5 \mathrm{Y}$ cells were analysed in the experiments reported in Figure 3. When these neuronal cells were incubated for 24 hours with increasing diclofenac concentrations, a dosedependent decrease of the SOD2 protein level was observed, as evaluated by Western blotting using antibodies against human SOD2 (Figure 3(a)). A similar picture emerged when SH-SY5Y cells were incubated with $150 \mu \mathrm{M}$ diclofenac and analysed at different times. The decrease of SOD2 levels (Figure 3(b)) was evident after 24-hour treatment and increased at 48 hours.

To investigate the possibility that the reduction of the SOD2 protein levels corresponded also to a decrease in SOD activity, the protein extracts obtained from cells incubated with $150 \mu \mathrm{M}$ diclofenac were analysed at different times using a SOD activity gel, which allows the detection of the activity 


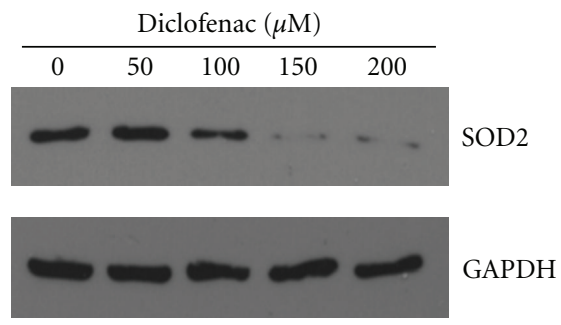

(a)

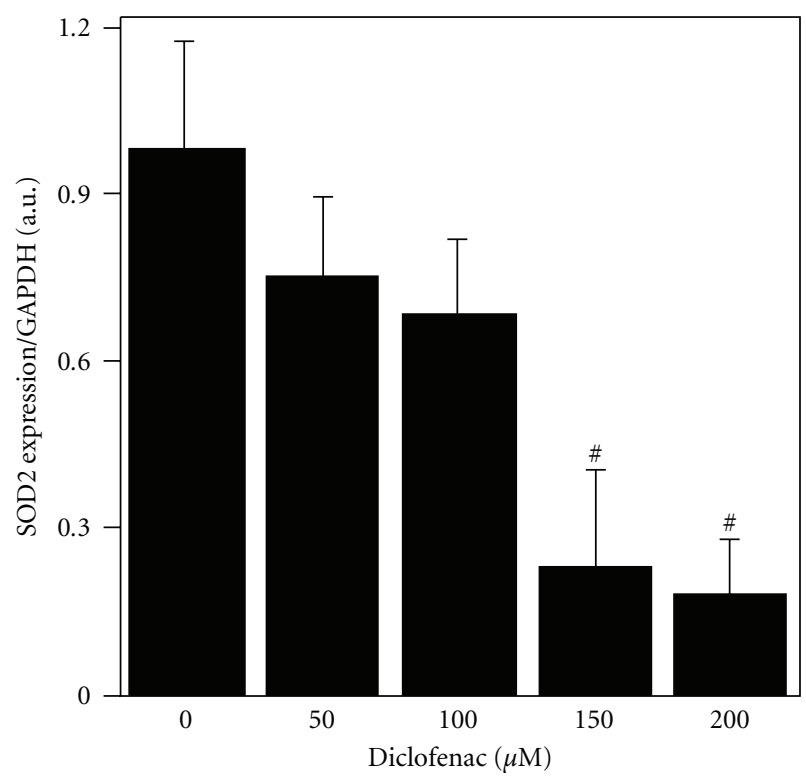

(c)

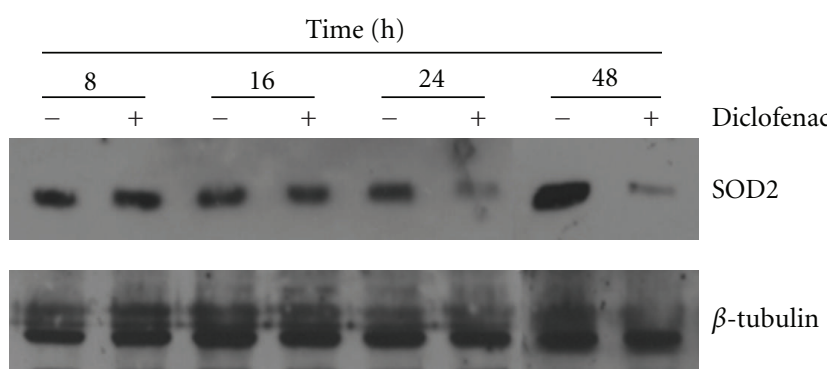

(b)

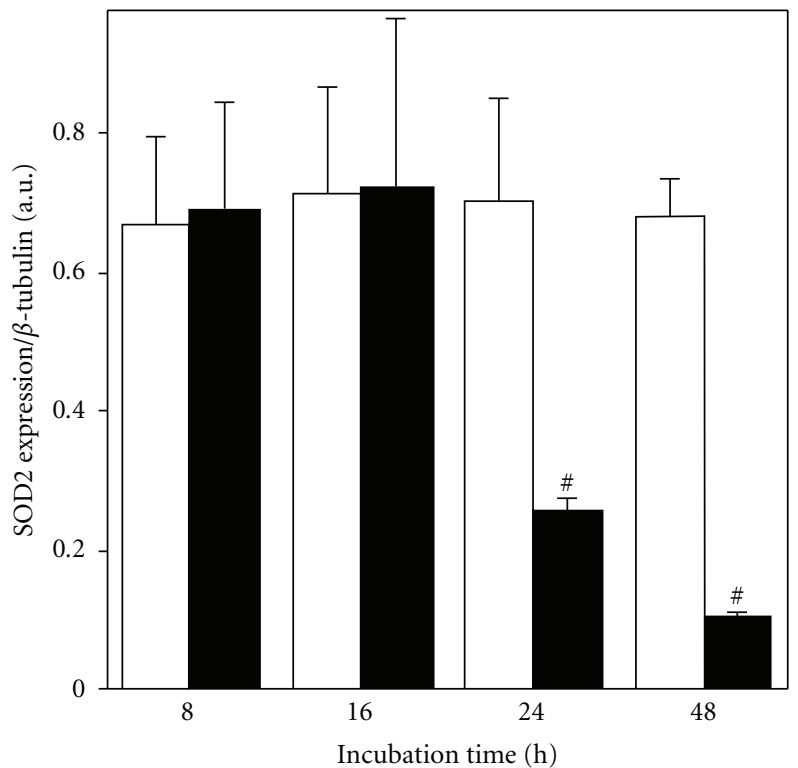

(d)

FIGURE 3: Effect of diclofenac on SOD2 protein levels. (a) Dose dependence. SH-SY5Y cells were incubated with the indicated concentrations of diclofenac for 24 hours. The SOD2 protein level was evaluated by immunoblotting; as a loading control, the same filter was probed with anti-GAPDH antibody. (b) Time dependence. SH-SY5Y cells were incubated with vehicle alone or $150 \mu \mathrm{M}$ diclofenac at the indicated times and treated as indicated in (a). $\beta$-tubulin was used as house-keeping control. (c, d) Densitometry evaluation of three independent experiments carried out as in (a) and (b), respectively; ${ }^{\#} P<.05$ compared to untreated cells.

of both mitochondrial SOD2 and cytosolic SOD1. Interestingly, the SOD2 activity decreased in a time-dependent manner (Figure 4), thus indicating that the reduction of the enzyme level caused a lower efficiency in the defence against the superoxide anions. Vice versa, the activity of SOD1 was not affected by the diclofenac treatment (not shown).

We also evaluated whether the diclofenac-induced decrease of SOD2 levels/activity depends on a downregulation of the corresponding mRNA. To this aim, $\mathrm{SH}-$ SY5Y cells were incubated in the presence or in the absence of $150 \mu \mathrm{M}$ diclofenac for 4,8 , and 24 hours. In order to evaluate a possible regulation of the enzyme at transcriptional level, after RNA extraction, a cDNA was obtained by reverse transcriptase and used as a template in a PCR realised in the presence of specific oligonucleotides for SOD2. The data presented in Figure 5 indicate that the diclofenac treatment did not significantly alter the mRNA levels of SOD2 at all times investigated. A similar picture with proportionally lower signals emerged when dilutions of the cDNA template were used in the RT-PCR assay (not shown). These results, together with the low number of amplification cycles used, confirm that the employed PCR conditions fell in the linear dose-response range.

3.4. Effect of a Heterologous Thioredoxin on the Antioxidant Power of Diclofenac-Treated Cells. Thioredoxin (Trx), a small $(12 \mathrm{kDa})$ and ubiquitous protein involved in many cellular functions, is a potent disulphide oxidoreductase controlling the reduced state of intracellular proteins. The crucial antioxidant power of Trx also takes advantage of its ability to cross the cellular membrane; in fact, evidences have been reported that $\operatorname{Trx}$ can be released from cells [26-28] and even enter a living cell [29, 30]. Moreover, endogenously produced or exogenously added Trx increases the SOD2 expression in lung carcinoma [31] or neuronal cells [32]. To this aim, the effect of TrxA2 from the hyperthermophilic archaeon Sulfolobus solfataricus (SsTrx) 


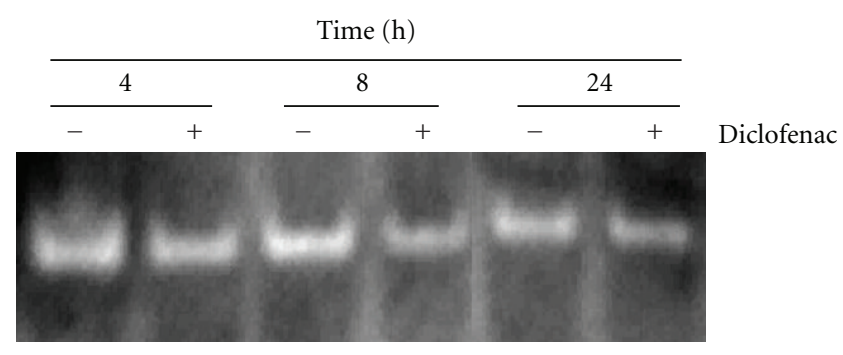

(a)

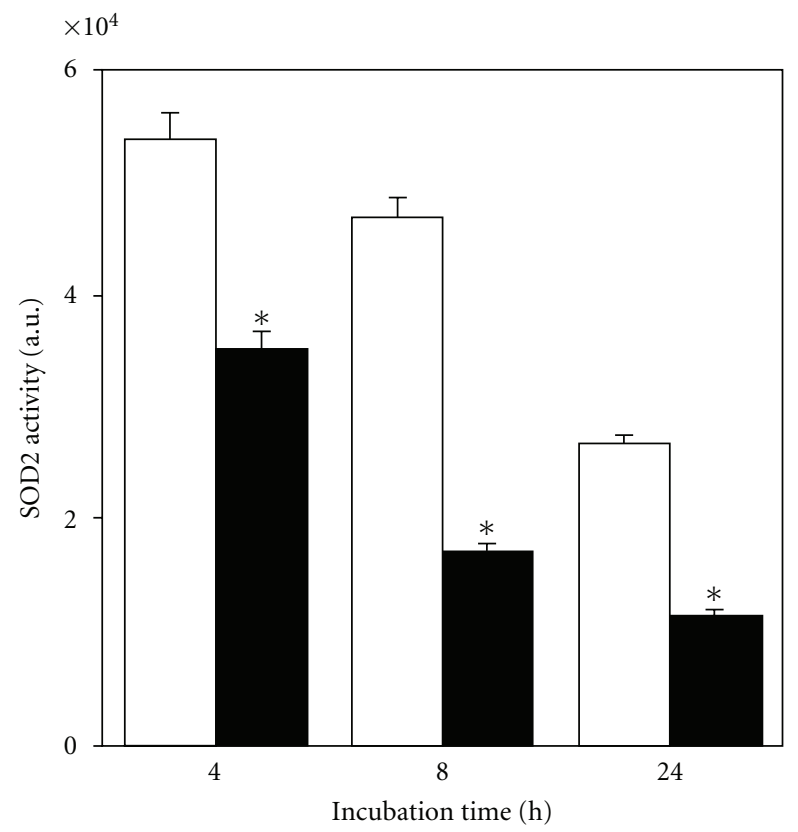

(b)

FIgURE 4: Effect of diclofenac on SOD2 activity. (a) SH-SY5Y cells were treated with vehicle alone or $150 \mu \mathrm{M}$ diclofenac for the indicated times. Total cell extracts were fractionated on a nondenaturing polyacrylamide gel and SOD2 activity was evaluated as described in Section 2.10. (b) Densitometry evaluation of three independent experiments; ${ }^{*} P<.01$ compared to untreated cells.

on the reduction of SOD2 levels caused by diclofenac was evaluated (Figure 6). When SH-SY5Y cells were treated with $150 \mu \mathrm{M}$ diclofenac, the SOD2 protein level was significantly reduced. The addition of increasing concentrations of $S s \operatorname{Trx}$ allowed a restoration of the SOD2 level, thus counteracting the effect of diclofenac. In particular, in the presence of $10 \mu \mathrm{M}$ SsTrx, the amount of SOD2 was even higher compared to untreated cells. In a control experiment, the addition of $10 \mu \mathrm{M}$ SsTrx did not cause any significant variation of the SOD2 level in the absence of diclofenac (not shown).

The possible protective effect of $S s \operatorname{Trx}$ on the diclofenacinduced apoptosis was also evaluated. As shown in Figure 7, the addition of $S s T r x$ partially reverted the programmed cell death provoked by the drug. In particular, in the presence of $10 \mu \mathrm{M} S s \operatorname{Trx}$, the apoptosis of the diclofenac-treated cells was reduced at all times investigated.

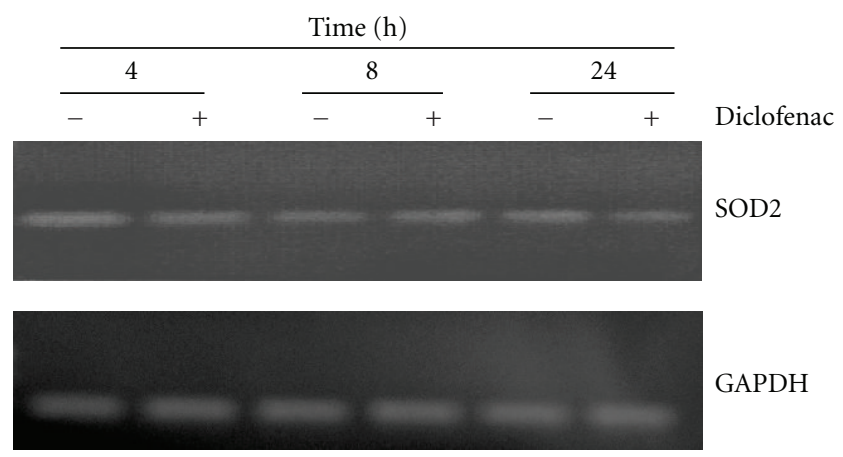

(a)

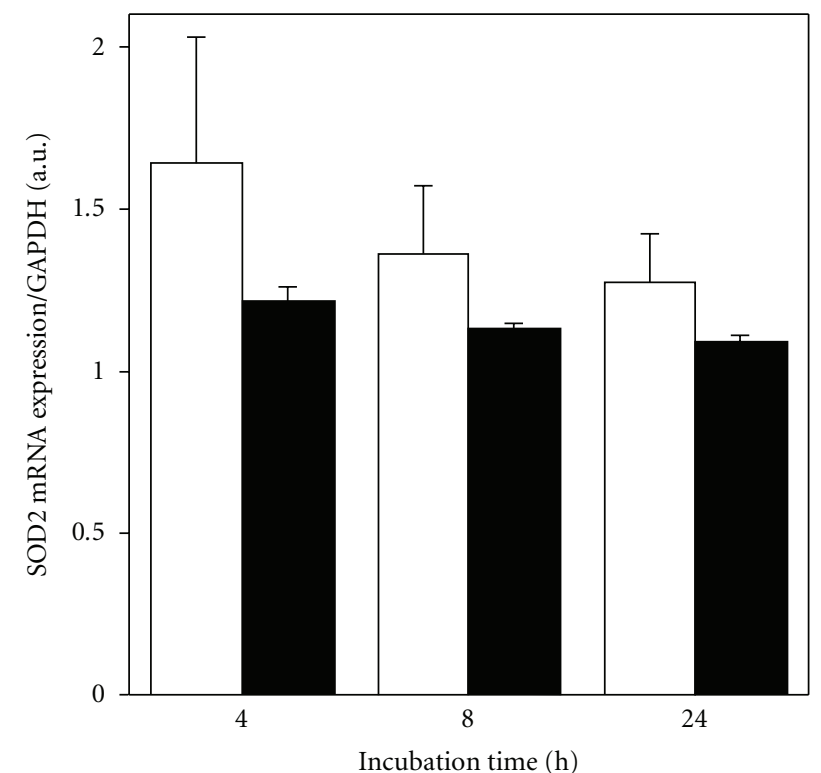

(b)

FIGURE 5: Analysis of SOD2 mRNA level in SH-SY5Y cells treated with diclofenac. (a) Total RNA extracts from SH-SY5Y cells, incubated with vehicle alone or $150 \mu \mathrm{M}$ diclofenac for the indicated times, were amplified by RT-PCR as indicated in Section 2.6 and analysed on a $1 \%$ agarose gel. As a control, the amplification of GADPH from the same extracts was carried out. (b) Densitometry evaluation of three independent experiments.

\subsection{Effect of Diclofenac on Mitochondrial Membrane Poten-} tial and Cytochrome $c$ Localization. Loss of the membrane mitochondrial potential occurs as an early event during the apoptosis induced by specific stimuli in some cellular systems [33]. To better evaluate the molecular mechanisms underlying the diclofenac-induced apoptosis in SH-SY5Y cells, the efficiency of the mitochondrial function was evaluated through measurements of its membrane potential, using the fluorescent probe R123. It is known that this compound crosses the mitochondrial membrane and accumulates into the matrix, only when the transmembrane potential is preserved; therefore, in case of a loss of the membrane potential, the R123 fluorescence undergoes a significant reduction [34]. As shown in Figure 8, the mitochondrial incorporation of R123 in SH-SY5Y cells treated with $150 \mu \mathrm{M}$ diclofenac underwent a significant reduction compared to 


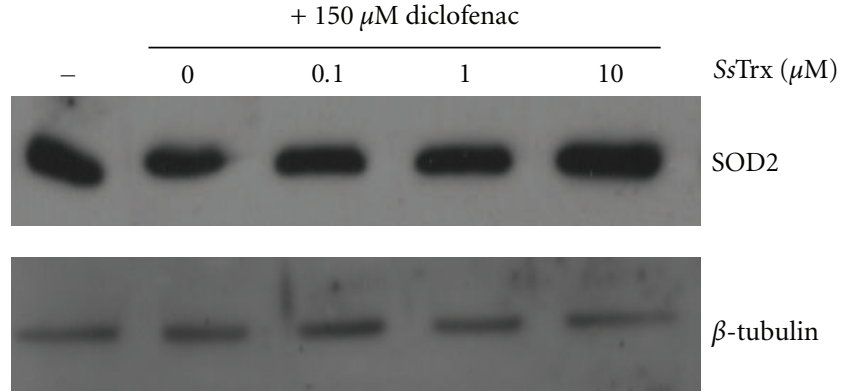

(a)

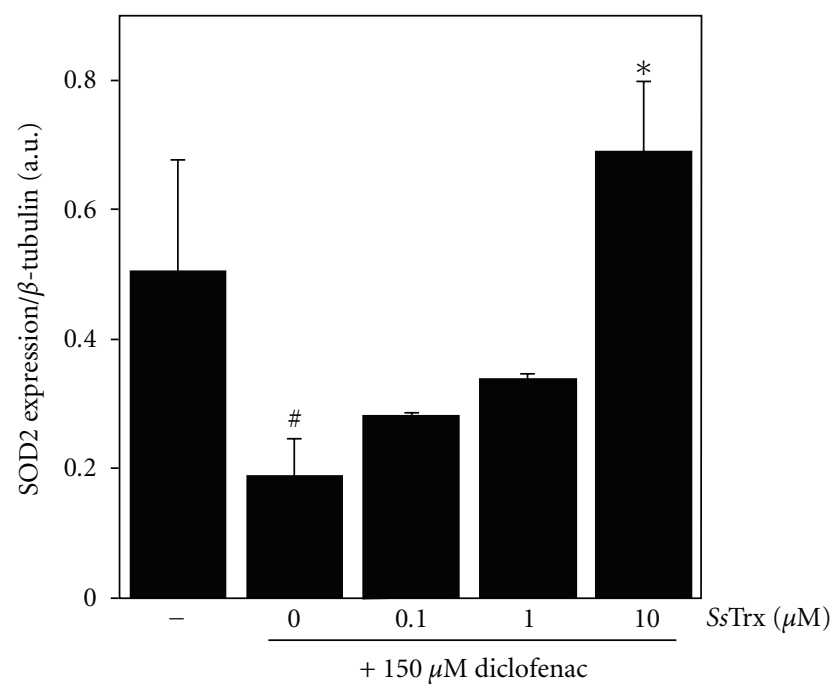

(b)

FIGURE 6: Effect of a heterologous thioredoxin on the reduced SOD2 protein level caused by diclofenac. (a) SH-SY5Y cells were incubated for 24 hours in the absence or in the presence of $150 \mu \mathrm{M}$ diclofenac plus the indicated concentrations of SsTrx. The SOD2 protein level was evaluated by immunoblotting. As a loading control, the same filter was probed with an anti- $\beta$-tubulin antibody. (b) Densitometry evaluation of three independent experiments; ${ }^{\#} P<.05$ compared to untreated cells; ${ }^{*} P<.01$ compared to diclofenac-treated cells.

that measured on untreated cells. This hypopolarization of the mitochondrial membrane caused by diclofenac became evident after 2-hour treatment and significantly increased with the incubation time.

A deeper insight on the involvement of mitochondria in the diclofenac-induced apoptosis was realised with a Western blotting analysis aimed at the evaluation of the cytochrome $c$ release from mitochondria. In particular, the detection of cytochrome $c$ was carried out on both cytosolic and mitochondrial protein fractions from SH-SY5Y cells incubated in the absence or in the presence of $150 \mu \mathrm{M}$ of diclofenac at different times (Figure 9). Interestingly, the cytochrome $c$ was already present after a 8 -hour incubation mainly in the cytosolic fraction of diclofenac-treated cells; moreover, the amount of this mitochondrial marker in the cytosol significantly increased after a 24-hour treatment (Figure 9(a)). This behaviour was confirmed by the concomitant analysis on the mitochondrial fraction, where a

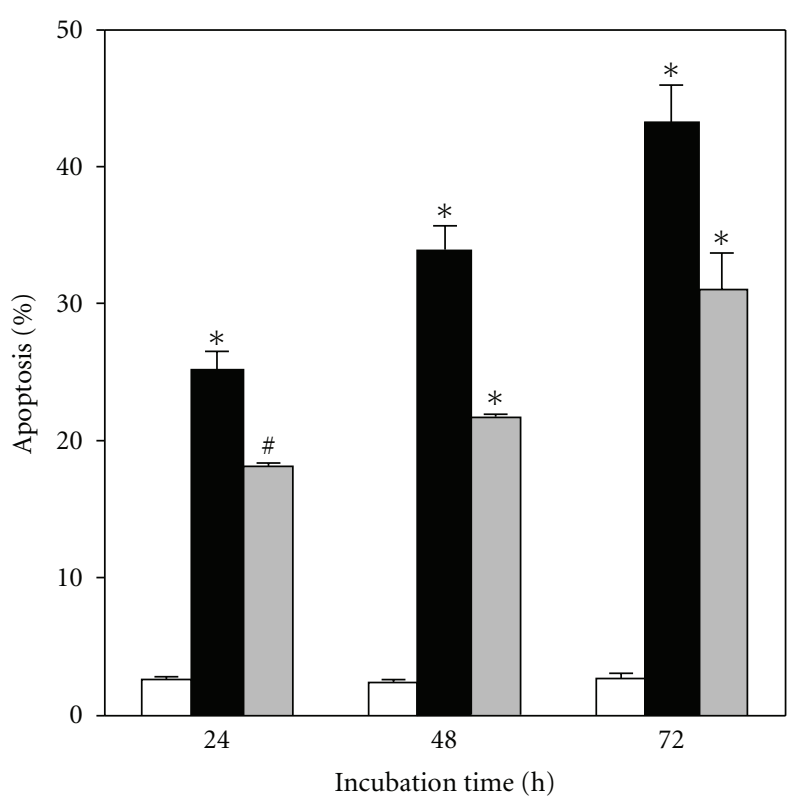

Figure 7: Partial reversion of the diclofenac-induced apoptosis by SsTrx. SH-SY5Y cells were incubated for the indicated times in the absence (white bars) or in the presence of $150 \mu \mathrm{M}$ diclofenac without (black bars) or with $10 \mu \mathrm{M}$ SsTrx (gray bars). The percentage of apoptosis was measured as described in Section 2.4; ${ }^{*} P<.01$ compared to untreated cells or diclofenac treated cells; ${ }^{\#} P<.05$ compared to diclofenac-treated cells.

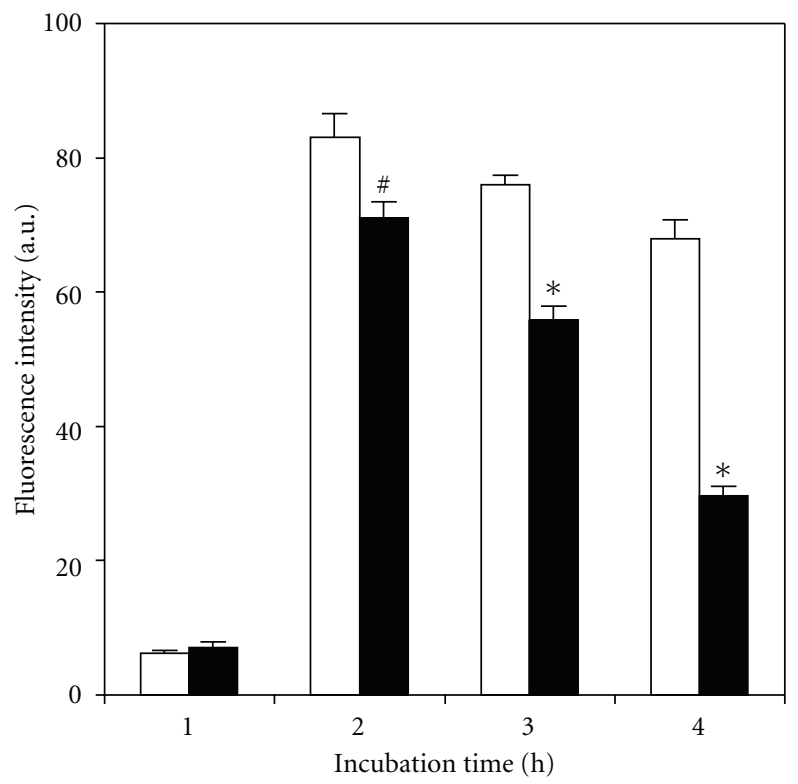

Figure 8: Reduction of the mitochondrial membrane potential in the presence of diclofenac. SH-SY5Y cells were incubated with vehicle alone (white bars) or $150 \mu \mathrm{M}$ diclofenac (black bars) for the indicated times. Mitochondrial membrane potential was evaluated through the incorporation of the fluorescent probe R123 as described in Section 2.7. ${ }^{*} P<.01$ and ${ }^{\#} P<.05$, compared to untreated cells. 


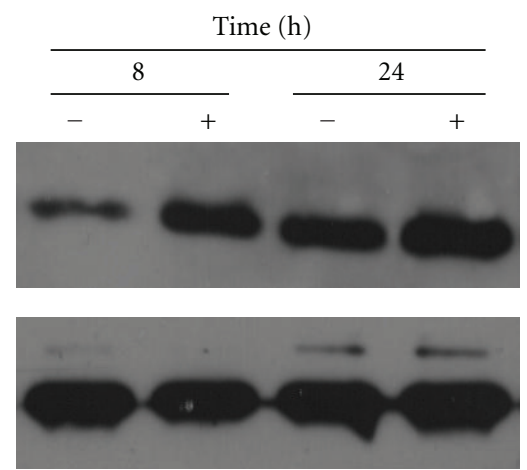

(a)

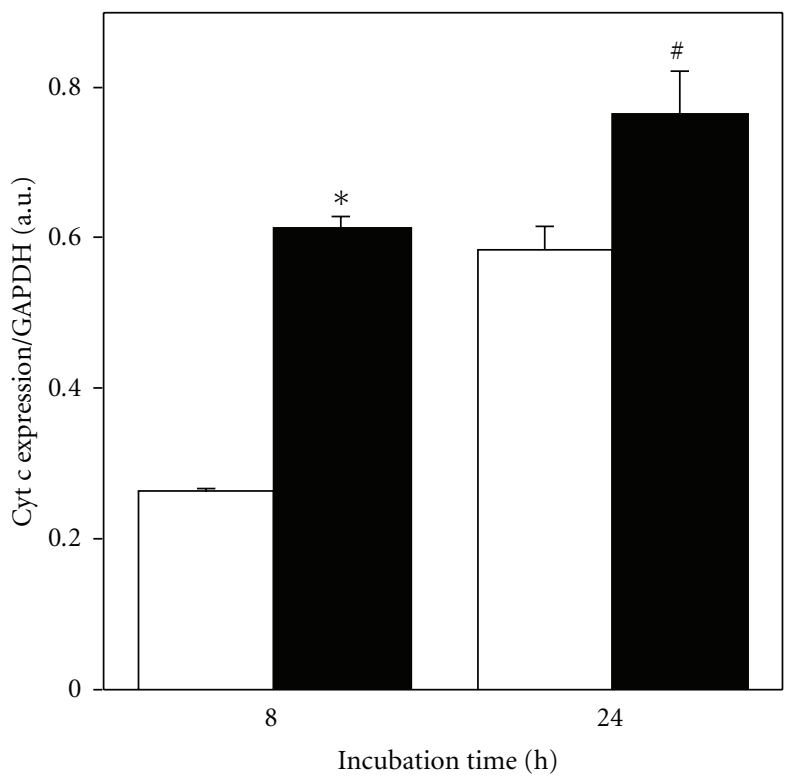

(c)

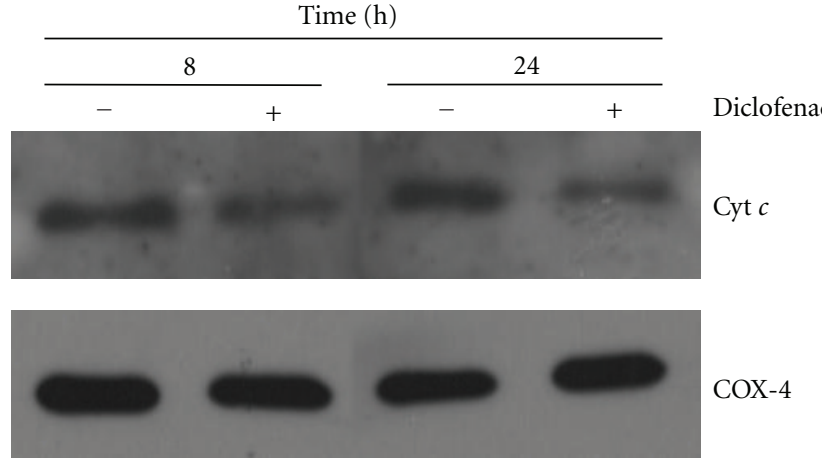

(b)

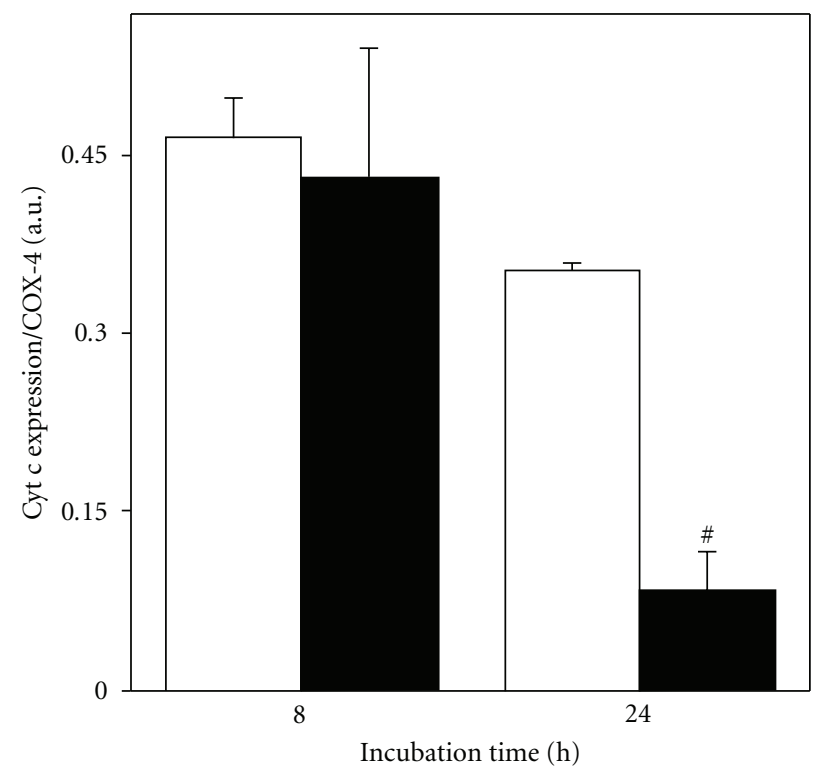

(d)

FIGURE 9: Effect of diclofenac on the subcellular distribution of cytochrome $c$. Cytosolic and mitochondrial fractions were prepared from SH-SY5Y cells incubated in the absence or in the presence of $150 \mu \mathrm{M}$ diclofenac for the indicated times. Distribution of cytochrome $c$ (Cyt c) in cytosolic (a) and mitochondrial (b) fraction was evaluated by immunoblotting. The same filters were also probed with anti-GAPDH (a) or anti-COX-4 (b) antibodies as loading control in the cytosolic or mitochondrial extracts, respectively. (c, d) Densitometry evaluation of three independent experiments carried out as in (a) and (b), respectively; ${ }^{*} P<.01$ and ${ }^{\#} P<.05$ compared to untreated cells.

reduction of the cytochrome $c$ level was observed in the diclofenac-treated cells (Figure 9(b)). These data indicate that cytochrome $c$ is released from the mitochondria, as a consequence of the diclofenac treatment of SH-SY5Y cells.

\section{Discussion}

In this paper we describe the effects of diclofenac on cultures of the neuroblastoma cell line SH-SY5Y, thus extending to this neuronal cell our knowledge on the possible toxicity of this drug, already reported for gastric, hepatic, or renal cells. Indeed, we present evidence that diclofenac induces apoptosis through a modulation of the mitochondrial function, associated to an alteration of the redox homeostasis.
It is known that apoptosis is the primary cell death induced by drugs [35] and that this process is mainly mediated by the mitochondrial pathway $[36,37]$. Here we show that diclofenac induces apoptosis of SH-SY5Y cells in a timeand concentration-dependent manner, thus suggesting that this compound is somehow toxic even for a neuronal-type cell. Previous pharmacokinetic studies demonstrated that the blood level of diclofenac, on the basis of the therapeutic doses used in patients (50-150 mg/day), ranges between 10 and $30 \mu \mathrm{M}$ [38]. However, in some circumstances the local concentration of the drug might increase. In particular, diclofenac concentration increases as a consequence of longterm treatments, overdosing, limited clearance, and so forth, as previously reported [39-42]. For these reasons, in our in vitro studies we have used a diclofenac concentration of $150 \mu \mathrm{M}$, because this value corresponded to the maximal 
concentration of this compound not causing cytotoxicity, as determined by cytotoxicity assays on SH-SY5Y cells. In the light of the large therapeutic usage of diclofenac, these data are more relevant because of the known ability of this drug to cross the blood-brain barrier [43]. Apoptosis is regulated by many signals and metabolic events, and the cellular redox state plays a critical role in this process. Indeed, several data showed that ROS, mainly produced by mitochondria, are involved in the programmed cell death through an induction of the oxidative stress [44]. In particular, an increased ROS level frequently represents a triggering event upstream of the mitochondrial membrane depolarization, cytochrome $c$ release, caspase activation, and nuclear fragmentation [45]. An alteration of the ROS levels was already demonstrated in diclofenac-induced apoptosis in gastric and renal cells $[9,10]$. Also in our neuronal cell system diclofenac provokes an early and significant increase of the intracellular ROS levels.

These results prompted us to evaluate the downstream effects of altered ROS levels in the course of diclofenac treatment of SH-SY5Y cells. Under this concern, SOD2 represents the major antioxidant enzyme in mitochondria, where the intense cellular respiration may produce a large amount of ROS. Therefore, an efficient SOD2 activity is required to counteract the mitochondrial dysfunction induced by an oxidative stress, which could lead to the programmed cell death usually observed in various disease contexts [46]. The antiapoptotic role of SOD2 is even demonstrated by the resistance to the radiation-induced damage reported for cell lines overexpressing SOD2 [47]. Our data on SH-SY5Y cells show that diclofenac impairs SOD2 functions, thus suggesting that this enzyme is involved in the apoptotic mechanism induced by the drug. In particular, this process is associated to a significant and concomitant reduction of both protein level and enzymatic activity of SOD2, whereas RT-PCR experiments showed that the corresponding mRNA levels are not affected by the diclofenac treatment. Therefore, a transcriptional regulation of the SOD2 gene by diclofenac could be excluded; probably, an increased degradation of the protein levels could explain the reduced activity of the enzyme. The behaviour of SOD2 in the diclofenac response was compared with the effects reported for other compounds in various experimental systems. For instance, stautosporine, a protein kinase inhibitor, did not affect the mRNA levels of SOD1 and SOD2, but decreased protein and activity levels of both enzymes [48]. Other authors reported that SOD2 is degraded by caspases in Jurkat T cells, following oligomerization of the Fas receptor [20]. On the other hand, in rat astrocytes the lipopolysaccharide induced an increase of SOD2 mRNA, but not of the SOD2 protein [49]. These observations confirm the regulation of SOD2 functions following a drug treatment; however, the differences observed among the various experimental systems indicate that the SOD2 response is a multifactorial process only poorly clarified.

It is known that the induction of SOD2 can be mediated by various macromolecules, such as interleukyn-1 [50], lipopolysaccarides [51], and tumor necrosis factor- $\alpha$ [52]; furthermore, thiol-reducing agents can affect SOD2 biosynthesis, as demonstrated by the enhanced SOD2 expression caused by thioredoxin, a potent disulfide oxidoreductase [31]. In this paper, the addition of a heterologous thioredoxin to diclofenac-treated cultures of SH-SY5Y led to an enhancement of the SOD2 levels, as well as to a reduction of the apoptosis. This result confirms the involvement of SOD2 in the apoptotic processes induced by the drug and suggests that an archaeal thioredoxin is active also in human cells. Furthermore, we can speculate on a possible functional interaction between heterologous components of the thioredoxin system, because purified archaeal SsTrx was added in its oxidised inactive form; its conversion to the reduced active form involves a reaction putatively catalysed by the human thioredoxin reductase.

The increased ROS level, the low functionality of the mitochondrial antioxidant enzyme SOD2, together with a partial recovery of SOD2 properties by a heterelogous thioredoxin, strongly suggest the involvement of mitochondria in the diclofenac-induced apoptosis of SH-SY5Y cells. This hypothesis was confirmed by measurements of the mitochondrial membrane potential. Indeed, an excessive production of ROS and a decrease in SOD2 levels contribute to the mitochondrial dysfunction. In particular, after a significant loss of the mithocondrial membrane potential, apoptosis-inducing factors are released from the mitochondria, thus leading to the activation of the caspase cascade, and ultimately to nuclear condensation $[44,45,53,54]$. Also in our system, the diclofenac treatment induces an early mitochondrial hypopolarization, correlated to an increase of the intracellular ROS levels, both events representing typical features of the onset of mitochondrial apoptosis. Another crucial marker of the intrinsic apoptosis is the cytocrome $c$ release from the mitochondria, as a consequence of membrane depolarization. Our data showed that cytochrome $c$ translocates from the mitochondria to the cytosol during the diclofenac treatment of SH-SY5Y cells. This finding, together with the mitochondrial membrane depolarization, provides a more direct link between mitochondria and diclofenacinduced apoptosis, thus confirming that the programmed cell death in SH-SY5Y follows the mitochondrial pathway.

The results obtained in this work could be relevant for a deeper insight on the therapeutic usage of diclofenac, pointing to the oxidative damage related to its cytotoxic effect. In particular, the involvement of the main antioxidant mitochondrial enzyme in the apoptotic process may suggest the use of SOD2 small interfering RNA in combination with diclofenac, in order to improve the treatment of cancer, such as neuroblastoma. On the other hand, diclofenac, because of its ability to alter the cellular redox state of neuronal cells, could be considered a neurotoxic compound. Under this concern, previous studies showed that diclofenac and indomethacin, another NSAID, enhance the effects of some neurotoxins on PC12 cells [55] and that diclofenac inhibits the proliferation and differentiation of neuronal stem cells [8]. Our results on the protective effects of SsTrx open some perspectives on the possible counteraction of the side effects caused by diclofenac. 


\section{Acknowledgments}

This work was supported by grants from MIUR, PRIN 2007, awarded to Emmanuele De Vendittis, Mariorosario Masullo, and Maria Rosaria Ruocco.

\section{References}

[1] M. Valko, D. Leibfritz, J. Moncol, M. T. D. Cronin, M. Mazur, and J. Telser, "Free radicals and antioxidants in normal physiological functions and human disease," International Journal of Biochemistry \& Cell Biology, vol. 39, no. 1, pp. 44-84, 2007.

[2] M. J. Gomez-Lechon, E. O'Connor, J. V. Castel, and R. Jover, "Sensitive markers used to identify compounds that trigger apoptosis in cultured hepatocytes," Toxicological Sciences, vol. 65, no. 2, pp. 299-308, 2002.

[3] M. J. Gomez-Lechon, X. Ponsoda, E. O'Connor, T. Donato, R. Jover, and J. V. Castell, "Diclofenac induces apoptosis in hepatocytes," Toxicology in Vitro, vol. 17, no. 5-6, pp. 675-680, 2003.

[4] S. Tsutsumi, T. Gotoh, W. Tomisato, et al., "Endoplasmic reticulum stress response is involved in nonsteroidal antiinflammatory drug-induced apoptosis," Cell Death and Differentiation, vol. 11, no. 9, pp. 1009-1016, 2004.

[5] M. J. Thun, S. J. Henley, and C. Patrono, "Nonsteroidal anti-inflammatory drugs as anticancer agents: mechanistic, pharmacologic, and clinical issues," Journal of the National Cancer Institute, vol. 94, no. 4, pp. 252-266, 2002.

[6] X. C. Xu, "COX-2 inhibitors in cancer treatment and prevention, a recent development," Anti-Cancer Drugs, vol. 13, no. 2, pp. 127-137, 2002.

[7] M. Lindskog, H. Gleissman, F. Ponthan, J. Castro, P. Kogner, and J. I. Johnsen, "Neuroblastoma cell death in response to docosahexaenoic acid: sensitization to chemotherapy and arsenic-induced oxidative stress," International Journal of Cancer, vol. 118, no. 10, pp. 2584-2593, 2006.

[8] C. Kudo, M. Kori, K. Matsuzaki, et al., "Diclofenac inhibits proliferation and differentiation of neural stem cells," Biochemical Pharmacology, vol. 66, no. 2, pp. 289-295, 2003.

[9] E. J. Hickey, R. R. Raje, V. E. Reid, S. M. Gross, and S. D. Ray, "Diclofenac induced in vivo nephrotoxicity may involve oxidative stress-mediated massive genomic DNA fragmentation and apoptotic cell death," Free Radical Biology \& Medicine, vol. 31, no. 2, pp. 139-152, 2001.

[10] H. Kusuhara, H. Komatsu, H. Sumichika, and K. Sugahara, "Reactive oxygen species are involved in the apoptosis induced by nonsteroidal anti-inflammatory drugs in cultured gastric cells," European Journal of Pharmacology, vol. 383, no. 3, pp. 331-337, 1999.

[11] M. J. Gomez-Lechon, X. Ponsoda, E. O'Connor, T. Donato, J. V. Castell, and R. Jover, "Diclofenac induces apoptosis in hepatocytes by alteration of mitochondrial function and generation of ROS," Biochemical Pharmacology, vol. 66, no. 11, pp. 2155-2167, 2003.

[12] C. Li, M. M. Wright, and R. M. Jackson, "Reactive species mediated injury of human lung epithelial cells after hypoxiareoxygenation," Experimental Lung Research, vol. 28, no. 5, pp. 373-389, 2002.

[13] G. Pani, B. Bedogni, R. Anzevino, et al., "Deregulated manganese superoxide dismutase expression and resistance to oxidative injury in p53-deficient cells," Cancer Research, vol. 60, no. 16, pp. 4654-4660, 2000.
[14] H. Tanaka, I. Matsumura, S. Ezoe, et al., "E2F1 and c-Myc potentiate apoptosis through inhibition of NF- $\kappa \mathrm{B}$ activity that facilitates MnSOD-mediated ROS elimination," Molecular Cell, vol. 9, no. 5, pp. 1017-1029, 2002.

[15] J. E. Kokoszka, P. Coskun, L. A. Esposito, and D. C. Wallace, "Increased mitochondrial oxidative stress in the Sod2 (+/-) mouse results in the age-related decline of mitochondrial function culminating in increased apoptosis," Proceedings of the National Academy of Sciences of the United States of America, vol. 98, no. 5, pp. 2278-2283, 2001.

[16] S. K. Manna, H. J. Zhang, T. Yan, L. W. Oberley, and B. B. Aggarwal, "Overexpression of manganese superoxide dismutase suppresses tumor necrosis factor-induced apoptosis and activation of nuclear transcription factor- $\kappa \mathrm{B}$ and activated protein-1," Journal of Biological Chemistry, vol. 273, no. 21, pp. 13245-13254, 1998.

[17] M. W. Epperly, C. A. Sikora, S. J. DeFilippi, et al., "Manganese superoxide dismutase (SOD2) inhibits radiation-induced apoptosis by stabilization of the mitochondrial membrane," Radiation Research, vol. 157, no. 5, pp. 568-577, 2002.

[18] M. W. Epperly, M. Bernarding, J. Gretton, M. Jefferson, S. Nie, and J. S. Greenberger, "Overexpression of the transgene for manganese superoxide dismutase (MnSOD) in 32D cl 3 cells prevents apoptosis induction by TNF- $\alpha$, IL-3 withdrawal, and ionizing radiation," Experimental Hematology, vol. 31, no. 6, pp. 465-474, 2003.

[19] T. Sato, T. Machida, S. Takahashi, et al., "Fas-mediated apoptosome formation is dependent on reactive oxygen species derived from mitochondrial permeability transition in Jurkat cells," Journal of Immunology, vol. 173, no. 1, pp. 285-296, 2004.

[20] M. Pardo, J. A. Melendez, and O. Tirosh, "Manganese superoxide dismutase inactivation during Fas (CD95)-mediated apoptosis in Jurkat T cells," Free Radical Biology \& Medicine, vol. 41, no. 12, pp. 1795-1806, 2006.

[21] P. Grimaldi, M. R. Ruocco, M. A. Lanzotti, et al., "Characterisation of the components of the thioredoxin system in the archaeon Sulfolobus solfataricus," Extremophiles, vol. 12, no. 4, pp. 553-562, 2008.

[22] X. Ponsoda, R. Jover, J. V. Castell, and M. J. GomezLechon, "Measurement of intracellular LDH activity in 96well cultures: a rapid and automated assay for cytotoxicity studies," Journal of Tissue Culture Methods, vol. 13, no. 1, pp. 21-24, 1991.

[23] I. Nicoletti, G. Migliorati, M. C. Pagliacci, F. Grignani, and C. Riccardi, "A rapid and simple method for measuring thymocyte apoptosis by propidium iodide staining and flow cytometry," Journal of Immunological Methods, vol. 139, no. 2, pp. 271-279, 1991.

[24] M. M. Bradford, "A rapid and sensitive method for the quantitation of microgram quantities of protein utilizing the principle of protein dye binding," Analytical Biochemistry, vol. 72, no. 1-2, pp. 248-254, 1976.

[25] C. Beauchamp and I. Fridovich, "Superoxide dismutase: improved assays and an assay applicable to acrylamide gels," Analytical Biochemistry, vol. 44, no. 1, pp. 276-287, 1971.

[26] N. Wakasugi, Y. Tagaya, H. Wakasugi, et al., "Adult Tcell leukemia-derived factor/thioredoxin, produced by both human T-lymphotropic virus type I- and Epstein-Barr virustransformed lymphocytes, acts as an autocrine growth factor and synergizes with interleukin 1 and interleukin 2," Proceedings of the National Academy of Sciences of the United States of America, vol. 87, no. 21, pp. 8282-8286, 1990. 
[27] A. Rosen, P. Lundman, M. Carlsson, et al., "A CD4 ${ }^{+}$T cell linesecreted factor, growth promoting for normal and leukemic B cells, identified as thioredoxin," International Immunology, vol. 7, no. 4, pp. 625-633, 1995.

[28] K. Pekkari, J. Avila-Cariño, A. Bengtsson, R. Gurunath, A. Scheynius, and A. Holmgren, "Truncated thioredoxin. (Trx80) induces production of interleukin-12 and enhances CD14 expression in human monocytes," Blood, vol. 97, no. 10, pp. 3184-3190, 2001.

[29] A. Spector, G. Z. Yan, R. R. C. Huang, M. J. McDermott, P. R. C. Gascoyne, and V. Pigiet, "The effect of $\mathrm{H}_{2} \mathrm{O}_{2}$ upon thioredoxin-enriched lens epithelial cells," Journal of Biological Chemistry, vol. 263, no. 10, pp. 4984-4990, 1988.

[30] M. R. Fernando, H. Nanri, S. Yoshitake, K. Nagata-Kuno, and S. Minakami, "Thioredoxin regenerates proteins inactivated by oxidative stress in endothelial cells," European Journal of Biochemistry, vol. 209, no. 3, pp. 917-922, 1992.

[31] K. C. Das, Y. Lewis-Molock, and C. W. White, "Elevation of manganese superoxide dismutase gene expression by thioredoxin," American Journal of Respiratory Cell and Molecular Biology, vol. 17, no. 6, pp. 713-726, 1997.

[32] T. Andoh, P. B. Chock, and C. C. Chiueh, "The roles of thioredoxin in protection against oxidative stress-induced apoptosis in SH-SY5Y cells," Journal of Biological Chemistry, vol. 277, no. 12, pp. 9655-9660, 2002.

[33] G. Kroemer and J. C. Reed, "Mitochondrial control of cell death," Nature Medicine, vol. 6, no. 5, pp. 513-519, 2000.

[34] L. V. Johnson, M. L. Walsh, B. J. Bockus, and L. B. Chen, "Monitoring of relative mitochondrial membrane potential in living cells by fluorescence microscopy," Journal of Cell Biology, vol. 88 , no. 3, pp. 526-535, 1981 .

[35] J. H. Gill and C. Dive, "Apoptosis: basic mechanisms and relevance to toxicology," in Apoptosis in Toxicology, R. Roberts, Ed., pp. 1-20, Taylor \& Francis, New York, NY, USA, 2000.

[36] N. Zamzami, C. Brenner, I. Marzo, S. A. Susin, and G. Kroemer, "Subcellular and submitochondrial mode of action of Bcl-2-like oncoproteins," Oncogene, vol. 16, no. 17, pp. 2265-2282, 1998.

[37] S. Fulda, S. A. Susin, G. Kroemer, and K.-M. Debatin, "Molecular ordering of apoptosis induced by anticancer drugs in neuroblastoma cells," Cancer Research, vol. 58, no. 19, pp. 4453-4460, 1998.

[38] B. Mukherjee, S. Mahapatra, S. Das, G. Roy, and S. Dey, "HPLC detection of plasma concentrations of diclofenac in human volunteers administered with povidone-ethylcellulosebased experimental transdermal matrix-type patches," Methods and Findings in Experimental and Clinical Pharmacology, vol. 28 , no. 5, pp. 301-306, 2006.

[39] W. Tang, "The metabolism of diclofenac-enzymology and toxicology perspectives," Current Drug Metabolism, vol. 4, no. 4, pp. 319-329, 2003.

[40] U. A. Boelsterli, "Diclofenac-induced liver injury: a paradigm of idiosyncratic drug toxicity," Toxicology and Applied Pharmacology, vol. 192, no. 3, pp. 307-322, 2003.

[41] Z. Yan, J. Li, N. Huebert, G. W. Caldwell, Y. Du, and H. Zhong, "Detection of a novel reactive metabolite of diclofenac: evidence for CYP2C9-mediated bioactivation via arene oxides," Drug Metabolism and Disposition, vol. 33, no. 6, pp. 706-713, 2005.

[42] B. Lauer, G. Tuschl, M. Kling, and S. O. Mueller, "Speciesspecific toxicity of diclofenac and troglitazone in primary human and rat hepatocytes," Chemico-Biological Interactions, vol. 179, no. 1, pp. 17-24, 2009.
[43] M. Fukuda, K. Kitaichi, F. Abe, et al., "Altered brain penetration of diclofenac and mefenamic acid, but not acetaminophen, in Shiga-like toxin II-treated mice," Journal of Pharmacological Sciences, vol. 97, no. 4, pp. 525-532, 2005.

[44] H. Q. Yin, Y. H. Kim, C. K. Moon, and B. H. Lee, "Reactive oxygen species-mediated induction of apoptosis by a plant alkaloid 6-methoxydihydrosanguinarine in HepG2 cells," Biochemical Pharmacology, vol. 70, no. 2, pp. 242-248, 2005.

[45] C. Sidoti-de Fraisse, V. Rincheval, Y. Risler, B. Mignotte, and J. L. Vayssière, "TNF- $\alpha$ activates at least two apoptotic signaling cascades," Oncogene, vol. 17, no. 13, pp. 1639-1651, 1998.

[46] L. A. Macmillan-Crow and D. L. Cruthirds, "Invited review: manganese superoxide dismutase in disease," Free Radical Research, vol. 34, no. 4, pp. 325-336, 2001.

[47] G. H. W. Wong, "Protective roles of cytokines against radiation: induction of mitochondrial MnSOD," Biochimica et Biophysica Acta, vol. 1271, no. 1, pp. 205-209, 1995.

[48] B. Ahlemeyer, E. Bauerbach, M. Plath, et al., "Retinoic acid reduces apoptosis and oxidative stress by preservation of SOD protein level," Free Radical Biology \& Medicine, vol. 30, no. 10, pp. 1067-1077, 2001.

[49] C. S. Niu, C. K. Chang, L. S. Lin, et al., "Modification of superoxide dismutase (SOD) mRNA and activity by a transient hypoxic stress in cultured glial cells," Neuroscience Letters, vol. 251, no. 3, pp. 145-148, 1998.

[50] G. A. Visner, W. C. Dougall, J. M. Wilson, I. A. Burr, and H. S. Nick, "Regulation of manganese superoxide dismutase by lipopolysaccharide, interleukin-1, and tumor necrosis factor. Role in the acute inflammatory response," Journal of Biological Chemistry, vol. 265, no. 5, pp. 2856-2864, 1990.

[51] K. Mokuno, K. Ohtani, A. Suzumura, et al., "Induction of manganese superoxide dismutase by cytokines and lipopolysaccharide in cultured mouse astrocytes," Journal of Neurochemistry, vol. 63, no. 2, pp. 612-616, 1994.

[52] G. H. W. Wong and D. V. Goeddel, "Induction of manganous superoxide dismutase by tumor necrosis factor: possible protective mechanism," Science, vol. 242, no. 4880, pp. 941944, 1988

[53] P. X. Petit, S. A. Susin, N. Zamzami, B. Mignotte, and G. Kroemer, "Mitochondria and programmed cell death: back to the future," FEBS Letters, vol. 396, no. 1, pp. 7-13, 1996.

[54] D. R. Green and G. Kroemer, "Pharmacological manipulation of cell death: clinical applications in sight?" Journal of Clinical Investigation, vol. 115, no. 10, pp. 2610-2617, 2005.

[55] N. Morioka, K. Kumagai, K. Morita, S. Kitayama, and T. Dohi, "Nonsteroidal anti-inflammatory drugs potentiate 1methyl-4-phenylpyridinium $\left(\mathrm{MPP}^{+}\right)$-induced cell death by promoting the intracellular accumulation of $\mathrm{MPP}^{+}$in $\mathrm{PC} 12$ cells," Journal of Pharmacology and Experimental Therapeutics, vol. 310, no. 2, pp. 800-807, 2004. 

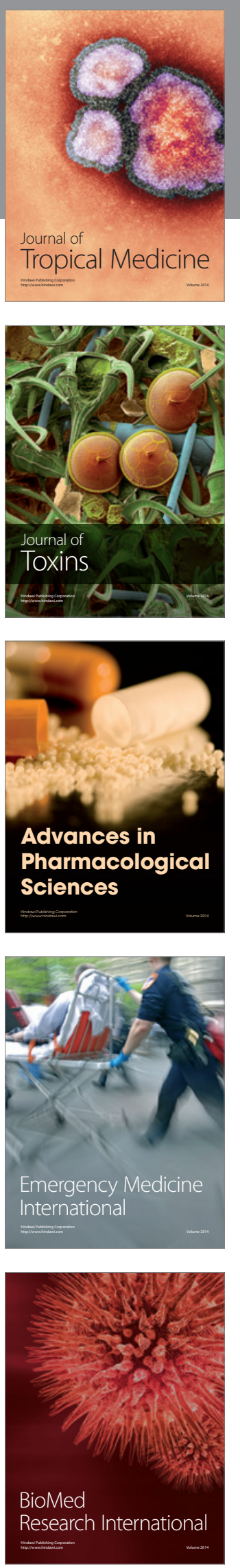
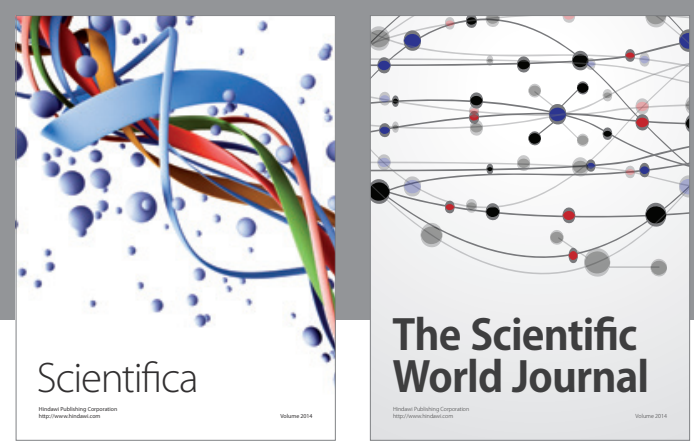

The Scientific World Journal
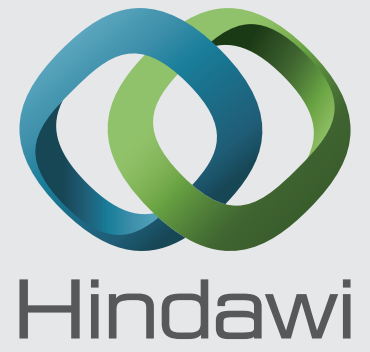

Submit your manuscripts at

http://www.hindawi.com
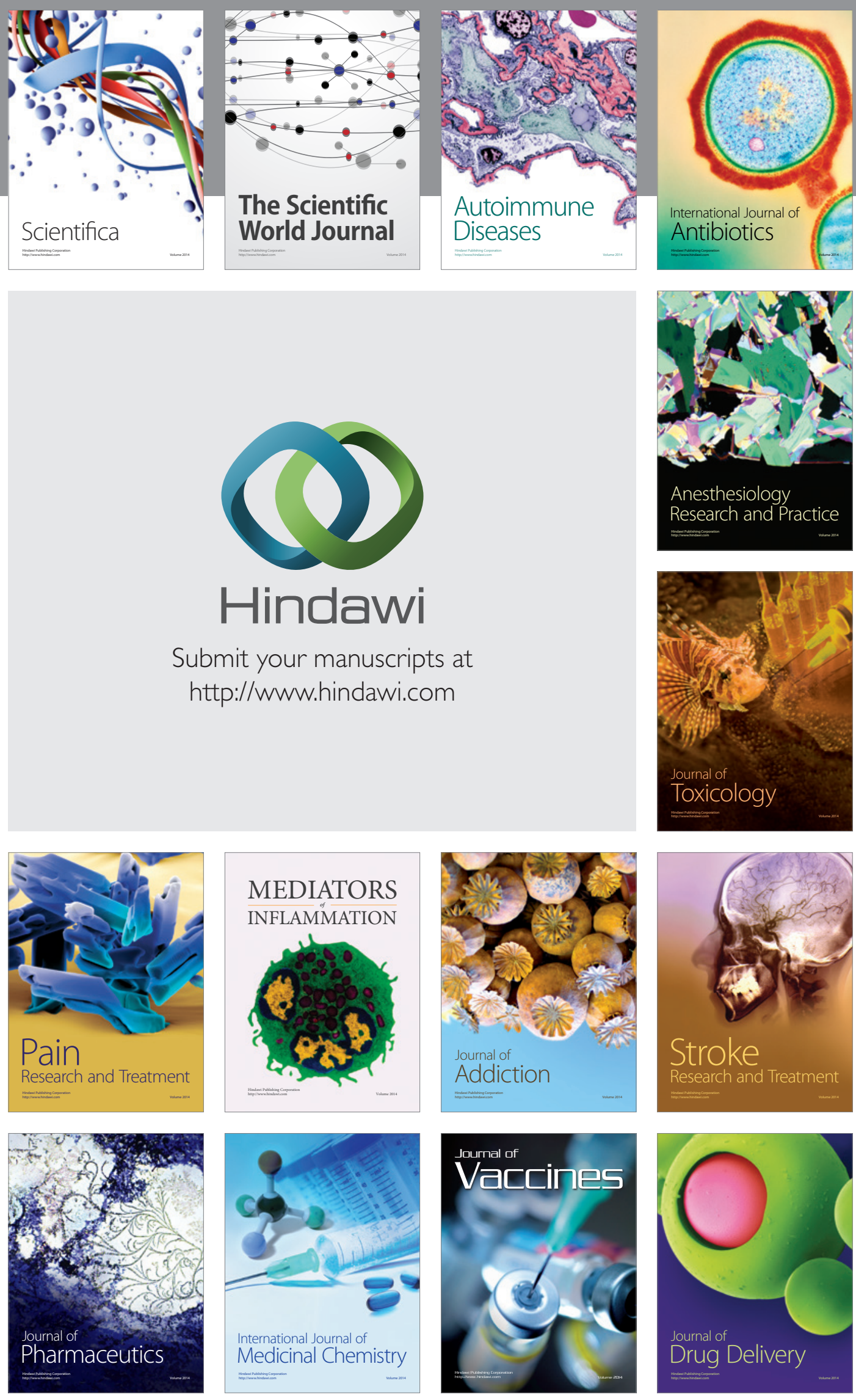